\title{
Movements and habitat use of satellite-tagged false killer whales around the main Hawaiian Islands
}

\author{
Robin W. Baird ${ }^{1, *}$, Gregory S. Schorr ${ }^{1}$, Daniel L. Webster ${ }^{1}$, Daniel J. McSweeney ${ }^{2}$, \\ M. Bradley Hanson ${ }^{3}$, Russel D. Andrews ${ }^{4}$ \\ ${ }^{1}$ Cascadia Research Collective, 2181/2 West 4th Avenue, Olympia, Washington 98501, USA \\ ${ }^{2}$ Wild Whale Research Foundation, PO Box 139, Holualoa, Hawai'i 96725, USA \\ ${ }^{3}$ NOAA Northwest Fisheries Science Center, 2725 Montlake Boulevard East, Seattle, Washington 98112, USA \\ ${ }^{4}$ School of Fisheries and Ocean Sciences, University of Alaska Fairbanks, Fairbanks, Alaska 99709, \\ and Alaska SeaLife Center, 301 Railway Avenue, Seward, Alaska 99664, USA
}

\begin{abstract}
There are 2 recognized stocks of false killer whales Pseudorca crassidens in the US Exclusive Economic Zone surrounding Hawai'i, a small demographically isolated population around the main Hawaiian Islands and a larger offshore ('pelagic') population. Recent evidence suggests the insular population may have declined precipitously over the last $20 \mathrm{yr}$, and one possible contributing factor is interactions with offshore longline fisheries or other hook and line fisheries. To assess movements and habitat use, satellite tags were remotely deployed on individuals in 3 groups from the insular population and one from the offshore population. Although tagged off the leeward side of the island of Hawai'i, individuals from the insular population regularly moved to the windward sides of the islands. Some insular individuals moved extensively and rapidly among islands, while other individuals remained associated with the island of Hawai'i for extended periods before moving among the other islands. Comparisons of distances between tagged individuals indicated that individuals within groups disassociated and re-associated over periods of days, occasionally moving more than $100 \mathrm{~km}$ apart before re-associating. The offshore individual, tagged $123.8 \mathrm{~km}$ offshore, approached to within $62 \mathrm{~km}$ of land, inshore of the longline fishery exclusion boundary. The 3 insular groups moved a maximum of 83, 87 and $96 \mathrm{~km}$ offshore, respectively, indicating that the distance from shore cannot be used as a strict boundary between the populations, and that individuals from the insular population may overlap with the longline fishery. When combined with photo-identification the results suggest that boundaries between these 2 stocks should be revised.
\end{abstract}

KEY WORDS: Longline fishing $\cdot$ Population boundaries $\cdot$ Group dynamics $\cdot$ Habitat use

\section{INTRODUCTION}

False killer whales Pseudorca crassidens are long lived and slow to mature, and have a low reproductive potential. Sexual maturity is reached at 8 to $14 \mathrm{yr}$ and interbirth intervals are estimated at 6.9 yr (Kasuya 1986, Purves \& Pilleri 1978). There is a small, demographically isolated population around the main Hawaiian Islands that appears to have undergone a large-scale decline in the last 20 yr (Baird et al. 2005, 2008a, Chivers et al. 2007, Reeves et al. 2009). Given the low productivity of the waters of the central tropical Pacific Ocean surrounding the Hawaiian Islands (Behrenfeld et al. 2006), and the high trophic level of false killer whales (Baird et al. 2008a), it is not surprising that the population size of false killer whales in Hawai'i is small. The best estimate of population size for the insular population is 123 individuals (coefficient of variation $[\mathrm{CV}]=0.72$ ), based on mark-recapture analyses of photographs taken between 2000 and 2004 (Baird et al. 2005). Much less is known regarding the offshore population in Hawaiian waters (Baird et al. 2008a), although the population size is thought to be about 4 times larger than the insular population (Barlow \& Rankin 2007). 
Studies in small boats using photo-identification and behavioral observations have provided more information on movements and site fidelity of individuals in the insular population in Hawai'i than for any other population of false killer whales in the world (Baird et al. 2008a), yet the rate of accumulation of information is slow, given the rarity of encounters. In $369 \mathrm{~d}$ of small-boat survey effort around the main Hawaiian Islands over a $7 \mathrm{yr}$ period (covering $38759 \mathrm{~km}$ of trackline), this species was only encountered on 18 occasions (Baird et al. 2008a). Based on photo-identification it is known that individuals move among islands, at least from $\mathrm{O}^{\prime} \mathrm{ahu}$ to Hawai'i, but nothing is known about use of the windward (east) sides of the islands or rates of movements (Baird et al. 2008a). Obtaining information on movement patterns is particularly important given that sighting rates in aerial surveys from 1992 to 2003 have declined significantly (J. Mobley unpubl. data), and there is additional evidence of a likely large decline in the size of the insular population over the last $20 \mathrm{yr}$ (Reeves et al. 2009). Knowledge of movement patterns can be used to assess both stock boundaries and interactions with fisheries.

False killer whales around the main Hawaiian Islands feed primarily on large game fish (Baird et al. 2008a) that are also commercially harvested, both in a variety of nearshore fisheries and the offshore Hawai'ibased longline fisheries (Gilman et al. 2007). This species interacts with the Hawai'i-based longline fisheries more frequently than any other species of marine mammal, both taking fish off lines and being hooked and sometimes killed as a result (Forney \& Kobayashi 2007). In the deep-set (i.e. tuna) component of the fishery, false killer whales represent almost two-thirds $(64.3 \%)$ of the cetaceans that are identified to species that are killed or seriously injured in the fishery (Forney \& Kobayashi 2007). Until 2009 only a single Hawaiian stock of false killer whales was officially recognized (Carretta et al. 2009), and since the first false killer whale population estimate and fisheries bycatch data became available in 2000 the estimated levels of mortality and serious injury of false killer whales in the longline fishery have exceeded the potential biological removal (PBR) level for that stock (Forney et al. 2000, Carretta et al. 2007). This situation recently resulted in a lawsuit against the US National Marine Fisheries Service (NMFS) for failing to create a take reduction team, and the evidence of a decline of the insular population has resulted in a petition for the species' listing under the Endangered Species Act by the Natural Resources Defense Council. Thus, information relevant to assessment of fisheries interactions is strongly needed for management and conservation purposes.

Since 1992 the Hawai'i-based longline fishery has been managed with a geographic exclusion zone around the main Hawaiian Islands that varies seasonally. From February through September the closest to the main Hawaiian Islands that longline fishing is allowed to occur is $79 \mathrm{~km}$, while from October through the end of January $66.3 \%$ of the longline fishery boundary contracts towards the islands, with some longline fishing occurring as close as $45 \mathrm{~km}$ from the main Hawaiian Islands (Fig. 1). Approximately $25 \%$ of the fishery boundary lies between 45 and $50 \mathrm{~km}$ from shore during this 4 mo period. Although Baird et al. (2008a) documented straight-line movements of up to $283 \mathrm{~km}$ by photo-identified individuals from the insular population, there has been very little survey effort offshore. With the low encounter rates it is unknown whether individuals from the insular population move far enough offshore to interact with the longline fishery. The longline exclusion boundary is currently considered by NMFS to be the provisional stock boundary between the Hawai'i 'insular' and Hawai'i 'pelagic' stocks of false killer whales, but it is expected that the stock boundary will be refined as additional data on movements of each stock become available (Carretta et al. 2009).

There is evidence from scarring patterns on some whales that individuals from the insular population may be interacting with
Fig. 1. Main Hawaiian Islands showing the $200 \mathrm{~m}$ isobath and the longline fishery exclusion boundaries. Along the south and west sides of the islands the 2 seasonal longline fishery exclusion boundaries overlap 
the fishery (Baird \& Gorgone 2005, T. Cullins unpubl. data). Although genetic analyses of samples from whales in fisheries bycatch have been identified only as offshore false killer whales (Chivers et al. 2007), only a sub-set of these observed individuals have been sampled, and the samples were collected 200 to $800 \mathrm{~km}$ from the main Hawaiian Islands. In addition, observer coverage is only approximately 20 to $25 \%$ in the deep-set component of the longline fishery, and $25 \%$ of the whales in the deep-set fishery bycatch are not identified to species (Forney \& Kobayashi 2007). Two whales in the bycatch were about 65 and $98 \mathrm{~km}$ east and north of the main Hawaiian Islands, respectively (Forney \& Kobayashi 2007); however, these individuals were not genetically sampled. The degree of overlap between the insular and offshore populations is poorly known, as is the distance from shore over which individuals from the insular population may range.

The purpose of our study is to examine movements of false killer whales around the main Hawaiian Islands using remotely deployed satellite tags. Given the low encounter rates with this species in Hawai'i and the difficulty of working in offshore and exposed areas, such tag deployments are the most productive way to answer questions regarding potential overlap of the insular and offshore populations, assess whether insular whales move far enough offshore to interact with the longline fishery, and examine movements among islands and along the windward sides of the islands. Information on movements may also be important to assess whether efforts to photo-identify individuals for mark-recapture analyses of population size result in biased estimates due to limited movements among the islands.

\section{MATERIALS AND METHODS}

Field operations were undertaken as part of a multispecies study of odontocetes in Hawaiian waters (see McSweeney et al. 2007, Baird et al. 2008b). The tags used were based on a design of Andrews et al. (2008) and have also been used on several other species of odontocetes (Schorr et al. 2009a, this Theme Section, 2009b). The tag contained an ARGOS-linked SPOT-5 location-only platform transmitter terminal (Wildlife Computers, Redmond, Washington, USA), with the tag attached by means of two $6.5 \mathrm{~cm}$ titanium darts and held in place with backward-facing petals. Dimensions of the tag (without darts) were $63 \times 30 \times 21 \mathrm{~mm}$, and the total weight of the entire tag package was approximately $49 \mathrm{~g}$. Tags were duty cycled, with transmissions 8 (December 2008), 12 (2007 and April 2008) or $13 \mathrm{~h} \mathrm{~d}^{-1}$ (July 2008) during either three or four 2 to $5 \mathrm{~h}$ blocks, with the blocks spread throughout the day corresponding to hours with the greatest density of satellite passes. Tags were remotely deployed on false killer whales using a Dan-Inject JM Special 25 pneumatic projector (Børkop, Denmark).

Photographs of tagged and companion individuals were compared with an existing photo-identification catalog that includes individuals from both the insular population and the offshore population, following the protocols described by Baird et al. (2008a). The existing catalog contained 152 distinctive and very distinctive individuals (individuals with multiple dorsal fin notches that could be identified among encounters even with fair or poor quality photos; see Baird et al. 2008a) documented from around the main Hawaiian Islands from 1986 through 2007, although given the long time span it is likely that not all individuals in the catalog are still alive. Information on sighting history and population identity was assessed through the sighting database compiled by Baird et al. (2008a). Age class (adult, subadult) of tagged individuals was estimated based on body size relative to other individuals, both in the field and in photographs, as well as by sighting history for some individuals. Putative sex of tagged whales was assessed based on the presence or absence of associated small calves or neonates for each individual over the entire sighting history for that individual, based on identifications in the catalog of Baird et al. (2008a).

Satellite-derived locations were assessed for plausibility using the Douglas Argos-Filter, v. 7.06 (available at: http://alaska.usgs.gov/science/biology/spatial/ douglas. html), using 2 independent methods (distance between consecutive locations, and rate and bearings among consecutive movement vectors). A number of variables are user-defined: location classes (LCs) that are automatically retained, maximum sustainable rate of movement, maximum redundant distance (consecutive points within a defined distance are kept by the filter), and the rate coefficient (Ratecoef) for assessing the angle created by 3 consecutive points. The rate coefficient algorithm takes into account that the farther an animal moves between locations, the less likely it is to return to or near to the original location without any intervening positions, creating an acute angle characteristic of typical Argos error. We automatically retained LC2 and LC3 locations, with estimated errors of $<500$ and $<250 \mathrm{~m}$, respectively (Argos User's Manual). LC1 locations (with estimated error of between 500 and $1500 \mathrm{~m}$ ), as well as LC0, LCA, LCB and LCZ locations (with no estimation of accuracy) were only retained if they passed the Douglas Argos-Filter process. For maximum sustainable rate of movement, we used $20 \mathrm{~km} \mathrm{~h}^{-1}$, based on maximum travel speeds noted during observations of fast-traveling false killer 
whales in Hawai'i (R. W. Baird pers. obs.). Maximum redundant distance was set at $3 \mathrm{~km}$, and Ratecoef was set at 25 .

After filtering, to examine movements of individuals in relation to one another, the straight-line distance among locations of pairs of individuals overlapping for extended periods $(>25$ d) were calculated with the Posdist function in Excel (Microsoft, available at: www.afsc.noaa.gov/nmml/software/excelgeo.php), using only locations that were obtained within 5 min of each other (i.e. during a single satellite overpass). In addition, locations of 5 different individuals that overlapped for a $10 \mathrm{~d}$ period, obtained within $\pm 6 \mathrm{~min}$ of each other, were animated to illustrate movements. Minimum rates of horizontal movement $\left(\mathrm{km} \mathrm{h}^{-1}\right)$ were calculated using pairs of locations obtained at intervals between 2 and $6 \mathrm{~h}$. These intervals were chosen to reduce the likelihood of spurious rates of movements associated either with poor location quality locations and short-time intervals (that would result in spurious high rates), or with long time intervals and a greater potential for directional reversals or changes (that would result in spurious low rates). Because of differences in duty cycling, rates of movements were only calculated for tags deployed in 2008. Minimum distances traveled (not taking into account movements around intervening land masses) were obtained by summing the straight-line distances among all locations for each individual.

A number of variables were populated for each filtered location using ArcGIS v. 9.2 (ESRI, Redlands, California), with point location data layered on a bathymetric raster surface. Continuous variables populated were depth, slope, distance to shore, distance to the $200 \mathrm{~m}$ isobath and distance to the FebruarySeptember and October-January longline exclusion boundaries. Whether locations were on the windward (north and east) or leeward sides (west) of the islands were assessed as a categorical variable, with locations in the channels between the islands categorized as windward if they were east or north of a line joining the closest points of Hawai'i and Maui, Maui and Moloka'i, Moloka'i and O'ahu, and O'ahu and Kaua'i (Fig. 1). Depths (m) were transferred to point locations using the 'intersect point tool' in Hawth's analysis tools (Beyer 2004). A $50 \times 50 \mathrm{~m}$ multibeam synthesis bathymetry model from the Hawai'i Mapping Research Group was used (available at: www.soest.hawaii.edu/HMRG/ Multibeam/index.php). The model had areas of no data, so the grid was overlaid on a 3 arc-second $(90 \times$ $90 \mathrm{~m}$ ) US Coastal Relief Model bathymetry from the National Geophysical Data Center (available at: www.ngdc.noaa.gov/mgg/coastal/coastal.html) to provide $90 \mathrm{~m}$ resolution data where $50 \mathrm{~m}$ resolution data were absent.
To assess individual variation in habitat use, comparisons of depths at satellite-derived locations among individuals was undertaken for 1 individual from each group of insular individuals tagged, and for 5 individuals tagged within a single group, over a $10 \mathrm{~d}$ period where location information was available for each individual. Comparisons were also made of depth use by individuals when they were closer to the island where they were tagged than to any other island, versus when they were closer to other islands, to address whether habitat use varies among the islands. This analysis was restricted to 2 individuals ( 1 from each of 2 groups) that had sufficient sample sizes from both areas. Comparisons of habitat use (depth, distance to the $200 \mathrm{~m}$ isobath, distance to shore) when individuals were on either on the windward or leeward sides of the islands was undertaken for individuals with more than 60 locations ( $>25$ for either windward or leeward locations) after filtering. All statistical comparisons were undertaken with Minitab 13.20 (www.minitab.com). Anderson-Darling normality tests were used to assess whether data were normally distributed, and parametric or non-parametric comparisons were undertaken as appropriate.

\section{RESULTS}

Satellite tags were deployed on 12 individual false killer whales on 5 different days (Table 1). Locations from tags were received for periods ranging from 2 to $76 \mathrm{~d}$ after tags were attached $($ mean $=32 \mathrm{~d}$, median $=$ $30 \mathrm{~d}$ ), with a total of 3076 locations after filtering with the Douglas Argos-Filter (Table 1). Eleven individuals were tagged nearshore $(<4 \mathrm{~km})$ off the west side of the island of Hawai'i. Identifications were obtained from all of these individuals; no individuals were tagged more than once, and all 11 had been previously documented off 1 or 2 other islands (Maui, O'ahu), 5 of which had also been previously documented off the island of Hawai'i. These 11 individuals were all linked by association with each other (see Table 3 ) and with the rest of the insular population (data not shown). After filtering with the Douglas Argos-Filter, on average $75.4 \%$ of the locations for these 11 individuals were LC3, LC2 or LC1 (Table 2). Of the 11 tagged insular individuals 7 were tagged on 2 different dates $10 \mathrm{~d}$ apart in July 2008, and tagged individuals from the first day were present on the second (Table 3). Thus, for the purposes of analyses these individuals were considered to be from a single group. While false killer whales do have some strong associations among individuals (Baird et al. 2008a), based on sighting histories (Table 3) individuals tagged in the other 2 insular groups (August 2007, December 2008) do not appear to be strongly linked with those tagged in July 2008. 
Table 1. Pseudorca crassidens. Information on false killer whales tagged and tag attachments (number of locations after filtering includes initial tagging location). Fe: female; Ma: male; M; Maui; O: O’ahu; H: Hawai'i; na: not applicable for offshore

\begin{tabular}{|c|c|c|c|c|c|c|c|c|c|c|c|}
\hline \multirow[t]{2}{*}{$\begin{array}{l}\text { Catalog } \\
\text { ID }\end{array}$} & \multirow[t]{2}{*}{ Age } & $\begin{array}{l}\text { Observati } \\
\text { to taggi } \\
\text { No. of } \\
\text { occasions }\end{array}$ & $\begin{array}{l}\text { ns prior } \\
\text { g day } \\
\text { Island }\end{array}$ & \multirow[t]{2}{*}{$\begin{array}{l}\text { Date } \\
\text { tagged }\end{array}$} & \multirow[t]{2}{*}{$\begin{array}{l}\text { Date last } \\
\text { location } \\
\text { obtained }\end{array}$} & \multirow[t]{2}{*}{$\begin{array}{c}\text { Min. no. } \\
\text { of days } \\
\text { of tag } \\
\text { attachment }\end{array}$} & \multirow[t]{2}{*}{$\begin{array}{c}\text { No. } \\
\text { of days } \\
\text { positions } \\
\text { obtained }\end{array}$} & \multirow[t]{2}{*}{$\begin{array}{l}\text { No. of } \\
\text { locations } \\
\text { after } \\
\text { filtering }\end{array}$} & \multicolumn{3}{|c|}{$\begin{array}{l}\text { Interval } \\
\text { between } \\
\text { consecutive } \\
\text { locations (h) }\end{array}$} \\
\hline & & & & & & & & & Mean & $\mathrm{SD}$ & Max. \\
\hline \multicolumn{12}{|c|}{ Insular population } \\
\hline HIPc217 & Adult & 1 & M & 15 Aug 07 & 29 Aug 07 & 14 & 14 & 57 & 6.0 & 6.3 & 22.2 \\
\hline HIPc276 & Adult & 1 & M & 15 Aug 07 & 17 Aug 07 & 2 & 2 & 13 & 4.2 & 7.1 & 23.6 \\
\hline HIPc107 & Adult & 4 & M & 15 Aug 07 & 16 Sep 07 & 32 & 29 & 131 & 5.9 & 8.6 & 70.6 \\
\hline HIPc272 & Subadult & 2 & $\mathrm{O}, \mathrm{H}$ & $16 \mathrm{Jul} 08$ & 30 Sep 08 & $76^{\mathrm{a}}$ & 26 & 254 & 2.3 & 2.3 & 11.3 \\
\hline HIPc179 & Adult & 3 & M, H & 16 Jul 08 & 22 Jul 08 & 6 & 6 & 66 & 2.3 & 2.7 & 10.7 \\
\hline HIPc202 & Adult & 4 & $\mathrm{O}, \mathrm{M}, \mathrm{H}$ & 16 Jul 08 & 10 Sep 08 & 56 & 56 & 697 & 1.9 & 2.0 & 10.8 \\
\hline HIPc145 & Adult Fe & 2 & $\mathrm{M}$ & $16 \mathrm{Jul} 08$ & 5 Aug 08 & 20 & 20 & 202 & 2.3 & 2.9 & 18.7 \\
\hline HIPc205 & Adult & 2 & M & 16 Jul 08 & 20 Aug 08 & 35 & 35 & 433 & 1.9 & 2.1 & 12.2 \\
\hline HIPc209 & Adult & 3 & $\mathrm{M}, \mathrm{O}$ & $26 \mathrm{Jul} 08$ & 14 Sep 08 & 50 & 50 & 504 & 2.4 & 2.7 & 14.7 \\
\hline HIPc213 & Adult Ma & 3 & $\mathrm{M}, \mathrm{H}$ & $26 \mathrm{Jul} 08$ & 23 Aug 08 & 28 & 28 & 302 & 2.3 & 2.6 & 12.6 \\
\hline HIPc172 & Adult Ma & 3 & $\mathrm{O}, \mathrm{H}$ & 10 Dec 08 & 2 Feb 09 & 54 & 54 & 405 & 3.1 & 2.9 & 19.1 \\
\hline \multicolumn{12}{|c|}{ Offshore population } \\
\hline PcTag $4^{\mathrm{b}}$ & Adult & 0 & na & 21 Apr 08 & 5 May 08 & 15 & 5 & 12 & 30.8 & 72.7 & 248.3 \\
\hline Mean & & & & & & 32 & 29 & & & & \\
\hline Total & & & & & & & 325 & 3076 & & & \\
\hline
\end{tabular}

Table 2. Pseudorca crassidens. Percentage of all locations for each individual that passed the Douglas Argos-Filter v. 7.06, by location class (LC)

\begin{tabular}{|c|c|c|c|c|c|c|c|}
\hline \multirow{2}{*}{$\begin{array}{l}\text { Catalog } \\
\text { ID }\end{array}$} & \multirow[b]{2}{*}{ LC 3} & \multirow[b]{2}{*}{ LC 2} & \multirow[b]{2}{*}{ LC 1} & \multirow{2}{*}{$\begin{array}{l}\text { Location class } \\
\text { LC } 0\end{array}$} & \multirow[b]{2}{*}{ LC A } & \multirow[b]{2}{*}{ LC B } & \multirow[b]{2}{*}{ LC Z } \\
\hline & & & & & & & \\
\hline \multicolumn{8}{|c|}{ Insular population } \\
\hline HIPc217 & 10.7 & 32.1 & 17.9 & 14.3 & 8.9 & 16.1 & 0.0 \\
\hline HIPc276 & 8.3 & 8.3 & 41.7 & 25.0 & 8.3 & 8.3 & 0.0 \\
\hline HIPc107 & 6.9 & 30.0 & 44.6 & 10.0 & 4.6 & 3.8 & 0.0 \\
\hline HIPc272 & 7.9 & 24.1 & 32.0 & 11.5 & 13.0 & 11.5 & 0.0 \\
\hline HIPc179 & 12.3 & 38.5 & 32.3 & 6.2 & 6.2 & 4.6 & 0.0 \\
\hline HIPc202 & 5.0 & 39.5 & 36.9 & 11.6 & 3.0 & 3.7 & 0.1 \\
\hline HIPc145 & 6.0 & 41.8 & 34.8 & 6.5 & 2.5 & 8.5 & 0.0 \\
\hline HIPc205 & 12.5 & 40.0 & 32.6 & 8.6 & 2.8 & 3.5 & 0.0 \\
\hline HIPc209 & 10.1 & 32.0 & 29.4 & 9.7 & 9.1 & 9.3 & 0.2 \\
\hline HIPc213 & 13.3 & 33.2 & 33.9 & 7.3 & 6.6 & 5.3 & 0.3 \\
\hline HIPc172 & 6.2 & 40.3 & 33.9 & 9.7 & 5.7 & 4.2 & 0.0 \\
\hline Mean & 9.0 & 32.7 & 33.6 & 10.9 & 6.4 & 7.2 & 0.1 \\
\hline \multicolumn{8}{|c|}{ Offshore population } \\
\hline PcTag4 & 0.0 & 9.1 & 9.1 & 0.0 & 18.2 & 63.6 & 0.0 \\
\hline
\end{tabular}

One individual was tagged on Jaggar Seamount, $123.8 \mathrm{~km}$ west of the island of Hawai'i, in a water depth of approximately $1460 \mathrm{~m}$. This individual was not photo-identified, but none of the 10 individuals in that encounter that were photo-identified had been previously documented, and a biopsy sample from one individual in this group was genetically identified with an offshore haplotype (Baird et al. 2008c).
Excluding the one individual for which locations were only received over a 2 d period (HIPc276), all tagged individuals from the insular population were documented moving from the leeward sides of the islands to the windward sides (Fig. 2). Five insular individuals were documented leaving the island of Hawai'i $3,7,20,47$ and $59 \mathrm{~d}$ after they were tagged (Table 4). Although, in all cases there were significant correla- 
Table 3. Pseudorca crassidens. Partial sighting history of tagged false killer whales. Data indicate that all tagged individuals from the insular population are linked by association (non-tagged individuals present are not shown). Identifications (X) of sighted whales are shown in bold on the date when they were tagged

\begin{tabular}{|c|c|c|c|c|c|c|c|c|c|c|c|}
\hline Date & HIPc217 & HIPc276 & HIPc107 & HIPc272 & HIPc179 & HIPc202 & HIPc145 & HIPc205 & HIPc209 & HIPc213 & HIPc172 \\
\hline 28 Feb 01 & & & $\mathrm{x}$ & & & & $\mathrm{X}$ & & & & \\
\hline 15 Apr 03 & & & $\mathrm{X}$ & & $\mathrm{X}$ & & & & & & \\
\hline 26 May 03 & & & & & & & & & & & $\mathrm{X}$ \\
\hline 21 Jan 04 & & $\mathrm{x}$ & & & & & $\mathrm{X}$ & & $\mathrm{x}$ & & \\
\hline $13 \mathrm{Sep} 04$ & & & & & $\mathrm{X}$ & & & & & & $\mathrm{X}$ \\
\hline 06 Oct 04 & & & & & & & & & & & $\mathrm{X}$ \\
\hline 30 Jan 05 & & & & & & & & & $\mathrm{x}$ & & \\
\hline 03 Mar 05 & $\mathrm{X}$ & & & & & $\mathrm{X}$ & & $\mathrm{X}$ & $\mathrm{x}$ & $\mathrm{X}$ & \\
\hline 21 Mar 05 & & & & & & & & & $\mathrm{x}$ & & \\
\hline $23 \mathrm{Feb} 06$ & & & & & & $\mathrm{X}$ & & $\mathrm{x}$ & & $\mathrm{X}$ & \\
\hline 11 Apr 06 & & & $\mathrm{x}$ & & $\mathrm{x}$ & $\mathrm{X}$ & & & & $\mathrm{X}$ & \\
\hline 09 Sep 06 & & & & $\mathrm{X}$ & & $\mathrm{X}$ & & & & $\mathrm{X}$ & \\
\hline 21 Nov 06 & & & & & & $\mathrm{X}$ & & & & & \\
\hline 15 Aug 07 & $\mathbf{x}$ & $\mathrm{x}$ & $\mathrm{x}$ & & & $\mathrm{X}$ & & & & & \\
\hline 08 Sep 07 & & & & & & & $\mathrm{X}$ & $\mathrm{X}$ & $\mathrm{X}$ & & \\
\hline 18 Oct 07 & & & & $\mathrm{X}$ & & & & & & & \\
\hline 08 Jan 08 & $\mathrm{X}$ & & & & & & & & $\mathrm{x}$ & & \\
\hline 26 Jun 08 & $\mathrm{X}$ & $\mathrm{x}$ & $\mathrm{X}$ & & & & & & & & \\
\hline $16 \mathrm{Jul} 08$ & & & & $\mathbf{x}$ & $\mathrm{x}$ & $\mathbf{X}$ & $\mathbf{x}$ & $\mathbf{X}$ & & & \\
\hline $26 \mathrm{Jul} 08$ & & & & $\mathrm{X}$ & & $\mathrm{X}^{\mathrm{a}}$ & $\mathrm{X}$ & $\mathrm{X}^{\mathrm{a}}$ & $\mathrm{x}$ & $\mathbf{X}$ & \\
\hline $27 \mathrm{Jul} 08$ & $\mathrm{X}$ & & $\mathrm{X}$ & $\mathrm{X}$ & $\mathrm{X}$ & & $\mathrm{X}^{\mathrm{a}}$ & $\mathrm{X}^{\mathrm{a}}$ & $\mathrm{x}$ & $\mathrm{X}^{\mathrm{a}}$ & \\
\hline 01 Aug 08 & & $\mathrm{X}$ & & & & & $\mathrm{X}$ & $\mathrm{X}$ & $\mathrm{X}$ & $\mathrm{X}$ & \\
\hline 04 Oct 08 & & $\mathrm{x}$ & & & & & & $\mathrm{X}$ & & & \\
\hline 04 Nov 08 & & & & & & & & & $\mathrm{X}$ & & \\
\hline 10 Dec 08 & & & & & & & & & & & $\mathbf{X}$ \\
\hline 26 Feb 09 & $\mathrm{X}$ & $\mathrm{X}$ & & & & & & & & & \\
\hline
\end{tabular}

tions between the time since tag deployment and the distance from the deployment site (regressions, p < 0.001), the movement patterns over time varied dramatically among individuals (Fig. 3). One individual tagged in August 2007 (HIPc107) left the island of Hawai'i after $3 \mathrm{~d}$ and moved among all the other main Hawaiian Islands including Kaua'i, moving a maximum distance of $95.9 \mathrm{~km}$ from shore (Table 4). Over 4 $\mathrm{d}(96 \mathrm{~h})$, locations of this individual were obtained consecutively closest to the islands of Hawai'i, Maui, Lana'i, O'ahu and Moloka'i, moving a minimum cumulative distance of $449.1 \mathrm{~km}$ in the $96 \mathrm{~h}$ period. One individual tagged in July 2008 (HIPc272) left the island 59 $\mathrm{d}$ after tagging and moved among all the main Hawaiian Islands except Kaua'i, moving a maximum distance offshore of $83.1 \mathrm{~km}$ (Table 4). The individual tagged in December 2008 (HIPc172) also moved among all the main Hawaiian Islands except to Kaua'i, moving a maximum distance offshore of $87.3 \mathrm{~km}$ (Fig. 4). This was the only individual tagged during the October through January period when the longline fishery boundary contracts towards the islands. For all 3 individuals locations greater than $80 \mathrm{~km}$ from shore were documented with good location qualities (HIPc107, $95.9 \mathrm{~km}, \mathrm{LC} 1$; HPc272, $81.7 \mathrm{~km}, \mathrm{LC} 2$; HIPc172,
$83.5 \mathrm{~km}, \mathrm{LC} 2)$. The closest points of approach to the longline boundary were 16.35 and $16.82 \mathrm{~km}$ (locations 31 min apart, both LC1s), on the windward side of the islands north of Maui (Fig. 2). The time interval from the last known location to the first of these closest locations was $3.4 \mathrm{~h}$, while the interval from the second close location to the next known location was $7.4 \mathrm{~h}$.

Excluding HIPc276, all of the insular individuals were documented over a broad range of depths, including both shallow $(<50 \mathrm{~m})$ and deep $(>1000 \mathrm{~m})$ areas. Five of the insular individuals (representing all 3 groups tagged) were documented using very deep water areas $(>4000 \mathrm{~m})$, although median depths used by all 11 insular individuals ranged from 163 to $1052 \mathrm{~m}$ (Table 4). Median depth used tended to increase with the number of days that movement data were available $\left(r^{2}=0.33\right)$ although this was not statistically significant (regression, $\mathrm{p}=0.062, \mathrm{n}=11$ ). For the 2 individuals that were located around both the island of Hawai'i and away from the island for $8 \mathrm{~d}$ or more (HIPc272, HIPc172, see Table 1), a broader range of depths were used when they were away from the island of Hawai'i (Fig. 5). Use of depths varied among the 5 individuals within the same group over a $10 \mathrm{~d}$ period (KruskallWallis 1-way ANOVA, p < 0.001), as well as among 3 
different groups of insular individuals, considering only a single individual from each group (KruskallWallis 1-way ANOVA, $\mathrm{p}<0.001$ ).

The farthest straight-line distance moved from the initial tagging location was $420.1 \mathrm{~km}$ (Table 4). Locations from the individual tagged offshore were obtained from $5 \mathrm{~d}$ over a $15 \mathrm{~d}$ period, although location

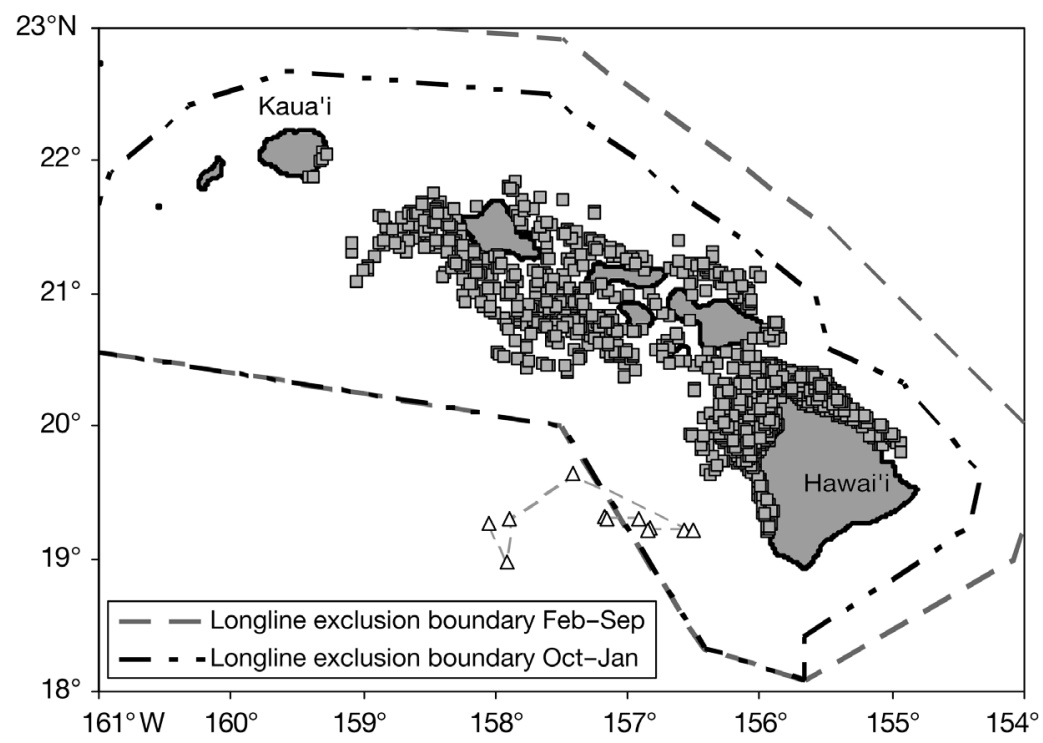

Fig. 2. Pseudorca crassidens. Locations of all satellite-tagged false killer whales after filtering. ( $\square$ ) Locations of individuals from the insular population; $(\Delta)$ individual from the offshore population (with consecutive points joined with dashed line). See Fig. 4 for detail of the offshore individual movements in relation to bathymetry qualities were relatively poor (Table 2). During this time this individual moved from 62.1 to $210.0 \mathrm{~km}$ offshore (Table 1), crossing the longline fishery exclusion boundary (Figs. $2 \& 4$ ).

Statistical comparisons of habitat use between the windward and leeward sides of the islands for the 9 insular individuals with $>60$ locations for windward and leeward sides combined ( $>25$ locations on each side) of the islands were not significant for the number of locations (paired $t$-test, $\mathrm{p}=0.071)$, median distance from the $200 \mathrm{~m}$ isobath (paired $t$-test, $\mathrm{p}=0.28$ ), median distance from shore (paired $t$-test, $\mathrm{p}=0.271$ ) or median depth (paired $t$-test, $\mathrm{p}=0.526$; Table 5). Significant differences were noted for maximum distance from the $200 \mathrm{~m}$ isobath (paired $t$-test, $\mathrm{p}=0.035$ ), maximum distance from shore (paired $t$-test, $\mathrm{p}=0.04$ ) and maximum depth (paired $t$-test, $\mathrm{p}=0.008$ ), with larger values observed for the leeward sides of the islands in all cases (Table 5).

Distance between pairs of individuals tagged on the same day increased significantly with time (HIPc202 and HIPc205, $\mathrm{r}^{2}=$ $0.14, \mathrm{p}<0.001$; HIPc209 and HIPc213, $\mathrm{r}^{2}=$ $0.09, \mathrm{p}<0001)$ but the relationships were weak (Fig. 6). Despite the general trend, over periods of $35 \mathrm{~d}$ (HIPc202 and HIPc205) and 29 d (HIPc209 and HIPc213) these pairs remained spatially associated (i.e. $<10 \mathrm{~km}$ apart) for periods ranging from a few hours up

Table 4. Pseudorca crassidens. Habitat use characteristics and movement information of tagged false killer whales determined from satellite-derived locations after filtering. Minimum distance traveled determined from straight-line distances among consecutive locations; maximum distance moved measured from tag deployment location; na: not applicable for offshore

\begin{tabular}{|c|c|c|c|c|c|}
\hline $\begin{array}{l}\text { Catalog } \\
\text { ID }\end{array}$ & $\begin{array}{l}\text { Median (range) } \\
\text { distance from } \\
\text { shore }(\mathrm{km})\end{array}$ & $\begin{array}{l}\text { Median (range) } \\
\text { depth (m) }\end{array}$ & $\begin{array}{l}\text { No. of days } \\
\text { associated with } \\
\text { island of Hawai'i } \\
\text { after tagging }\end{array}$ & $\begin{array}{l}\text { Min. distance } \\
\text { travelled } \\
(\mathrm{km})\end{array}$ & $\begin{array}{l}\text { Max. distance } \\
\text { moved } \\
(\mathrm{km})\end{array}$ \\
\hline \multicolumn{6}{|c|}{ Insular population } \\
\hline HIPc217 & $6.4(0.1-35.3)$ & $220(10-1742)$ & 6 & 1068 & 211.0 \\
\hline HIPc276 & $5.4(0.1-10.1)$ & $163(6-564)$ & $2^{\mathrm{a}}$ & 99 & 52.5 \\
\hline HIPc107 & $14.1(1.6-95.9)$ & $597(46-4833)$ & 2 & 2612 & 420.1 \\
\hline HIPc272 & $20.5(0.9-83.1)$ & $827(46-4767)$ & 58 & 3010 & 329.9 \\
\hline HIPc179 & $11.9(0.4-33.7)$ & $697(11-1673)$ & $6^{\mathrm{a}}$ & 862 & 113.5 \\
\hline HIPc202 & $14.0(0.1-37.9)$ & $754(12-4652)$ & $56^{\mathrm{a}}$ & 7268 & 117.8 \\
\hline HIPc145 & $6.3(0.1-27.4)$ & $392(6-2105)$ & $20^{\mathrm{a}}$ & 2174 & 104.2 \\
\hline HIPc205 & $9.8(0.1-31.7)$ & $614(1-2619)$ & $35^{\mathrm{a}}$ & 4659 & 108.0 \\
\hline HIPc209 & $7.7(0.1-39.3)$ & $416(8-3401)$ & 46 & 5633 & 313.2 \\
\hline HIPc213 & $10.1(1.2-28.7)$ & 595 (46-1940) & $28^{\mathrm{a}}$ & 3415 & 117.7 \\
\hline HIPc172 & $22.7(2.7-87.3)$ & $1052(94-4847)$ & 19 & 5653 & 330.7 \\
\hline Grand mean & $11.7(5.4-22.7)$ & $575(163-1052)$ & & & \\
\hline \multicolumn{6}{|c|}{ Offshore population } \\
\hline PcTag4 & $122.8(62.1-210.0)$ & $3844(1474-4747)$ & na & 324 & 95.1 \\
\hline
\end{tabular}



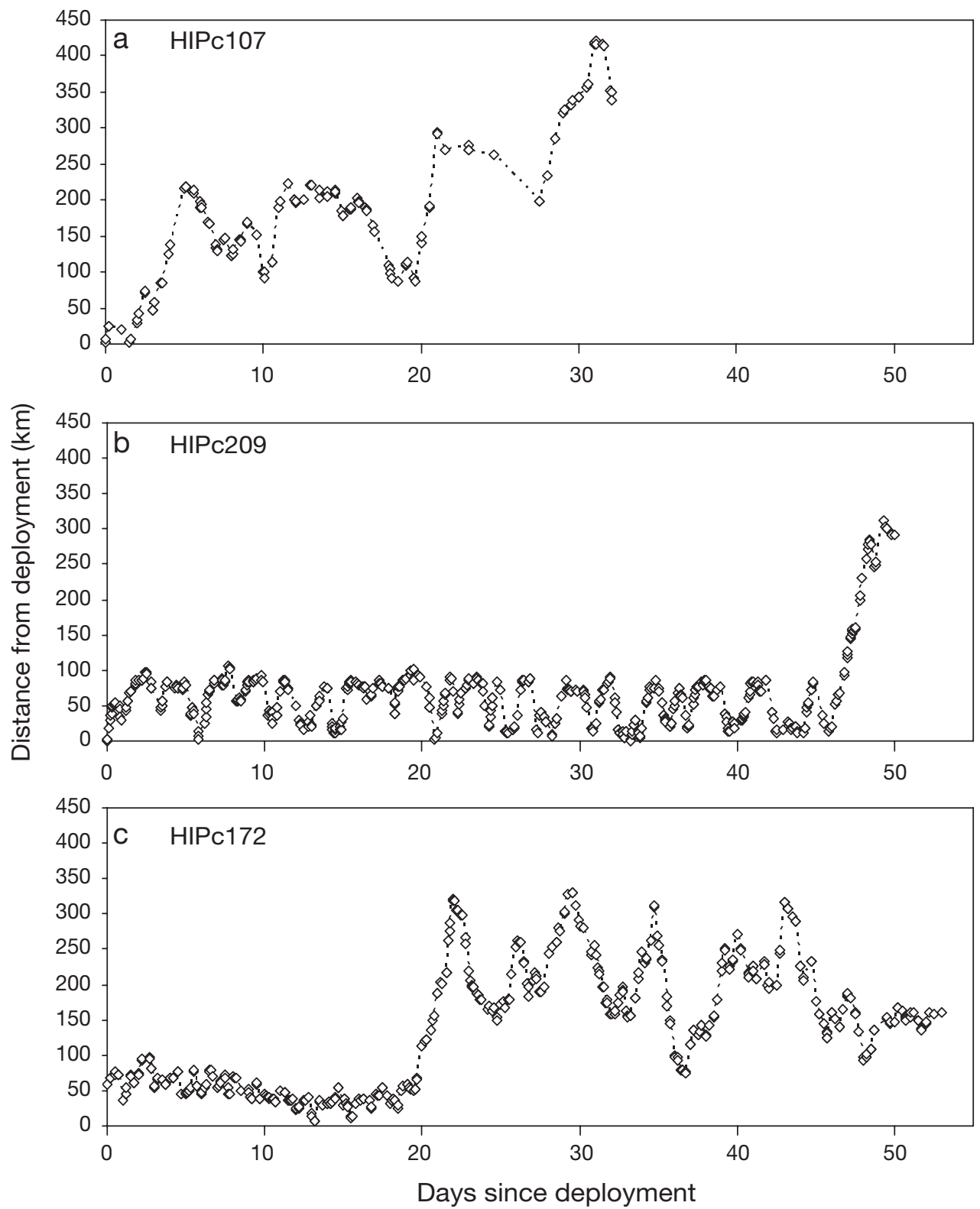

Fig. 3. Pseudorca crassidens. Distance from deployment location versus the days since deployment for 1 individual from each of 3 groups of insular false killer whales tagged, illustrating differences in movement patterns. (a) HIPc107, tagged in August 2007, remained associated with the island for just 3 d before traveling among the islands, eventually reaching Kaua'i on Day 31. (b) HIPc209, tagged in July 2008, remained associated with the island and frequently returned close to the area where it was tagged during the first 46 d, before traveling away from the island on Day 47. (c) HIPc172, tagged in December 2008, remained associated with the island for $20 \mathrm{~d}$ before traveling among the islands. The observed cyclical pattern results from individuals circumnavigating other islands (i.e. O'ahu, Moloka'i, Maui, HIPc107, HIPc172) and thus approaching closer to the tagging site, or transiting to the windward side of the island and back repeatedly (HIPc209)

to approximately $11 \mathrm{~d}$, but also separated (by up to 104.2 and $105.6 \mathrm{~km}$ for the 2 pairs, respectively) for periods of up to $3 \mathrm{~d}$ (Fig. 6). The satellite-derived locations for the 2 individuals in each pair were within $10 \mathrm{~km}$ of each other for 78.8 and $60.7 \%$ of their time, respectively. The median distance between locations for individuals in each pair were $3.1 \mathrm{~km}(\mathrm{n}=383$ pairs of locations) and $6.7 \mathrm{~km}(\mathrm{n}=247)$, respectively. An animation of movements of 5 individuals over a $10 \mathrm{~d}$ period is shown in Video S1 (available at www.intres.com/articles/suppl/n010p107_app/). Average rates of horizontal movements (sustained over periods of 2 to $5 \mathrm{~h}$ ) ranged from 4.38 to $5.71 \mathrm{~km} \mathrm{~h}^{-1}$, with maximum rates of up to $18.61 \mathrm{~km} \mathrm{~h}^{-1}$ (Table 6). 

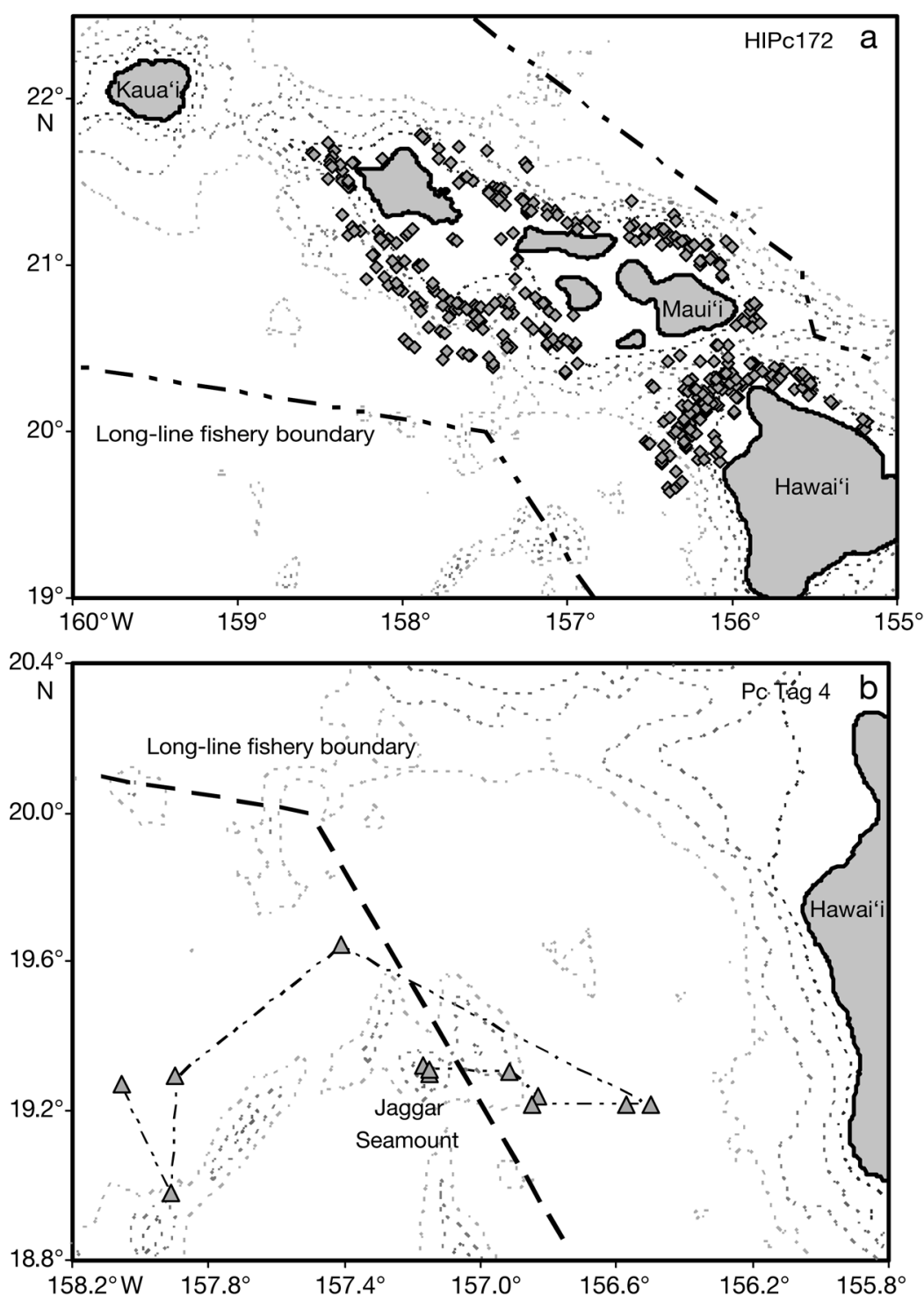

Fig. 4. Locations of 2 individual satellite-tagged false killer whales: (a) HIPc172, insular population; (b) PcTag4, offshore population. Lines connecting locations of PcTag4 show temporal patterns but do not necessarily reflect exact travel routes among locations. The offshore individual was tagged on Jaggar Seamount 21 April 2008, with the closest approach to land $(62 \mathrm{~km})$ documented on 22 April. See Fig. 3 for distance moved over time for HIPc172. The 1000, 2000, 3000 and $4000 \mathrm{~m}$ depth contours and the longline fishery exclusion boundary are shown

\section{DISCUSSION}

Deployment of satellite tags on individual false killer whales around the main Hawaiian Islands has greatly added to our understanding of movements and spatial use by this species, as well as providing insights into group dynamics. In addition, we have obtained the first movement information available for an individual from the offshore population in Hawaiian waters, with implications for a stock boundary between these populations. However, there are several important caveats that must be considered in terms of the scope of our conclusions. Despite the fact that we tagged 11 individuals from the insular population and obtained movement information spanning an average of over $30 \mathrm{~d}$ per individual, our data effectively represent the movements of just 3 groups of false killer whales. Movement data were primarily restricted to 5 different months of the year (with the exception of $2 \mathrm{~d}$ of data from February 2009), and with respect to movements in relation to the longline fishery exclusion zone boundary, only 1 individual was tagged during the period when the boundary contracts towards the islands. Thus, while we can determine what our satellite tagged individuals did and suggest implications for what the population may do, it is important to recognize that the great degree of variation documented with our small sample suggests individuals in the population use areas not used by our tagged whales during the short period they were tagged, and potentially exhibit a far greater degree of variability in movement patterns than we have documented with this sample. Inherent error in Argos locations also adds some uncertainty to the precise locations of tagged whales, although the high proportion of good quality locations for individuals from the insular population (LC3s, LC2s and LC1s: mean $=75.4 \%$, Table 2 ) suggests that potential bias associated with location quality should be minimal. In addition, given the mean time interval between consecutive locations for tagged individuals from the insular population ranged from 1.9 to $6.0 \mathrm{~h}$ (with maximum intervals of up to $70.6 \mathrm{~h}$, Table 1), with the high rates of movements documented (Table 6) our tagged individuals could have used areas not indicated by the location data obtained.

Overall our results support previous information available from genetic analyses (Chivers et al. 2007) and photo-identification (Baird et al. 2008a) that there is an island-associated population of false killer whales in Hawai'i. Over periods of weeks to about 2 mo satellite-tagged individuals remained associated with the main Hawaiian Islands (Fig. 2, Table 4). Rather than remaining in shallow nearshore waters as do several other species of islandassociated odontocetes in Hawaiian waters (e.g. spinner dolphins Stenella longirostris and common bot- 
tlenose dolphins Tursiops truncatus; Norris et al. 1994, Baird et al. 2009), tagged individuals were an average of almost $12 \mathrm{~km}$ offshore in $575 \mathrm{~m}$ of water (Table 4). Despite average cumulative movement distances of about $3300 \mathrm{~km}$ per individual (Table 4), the average

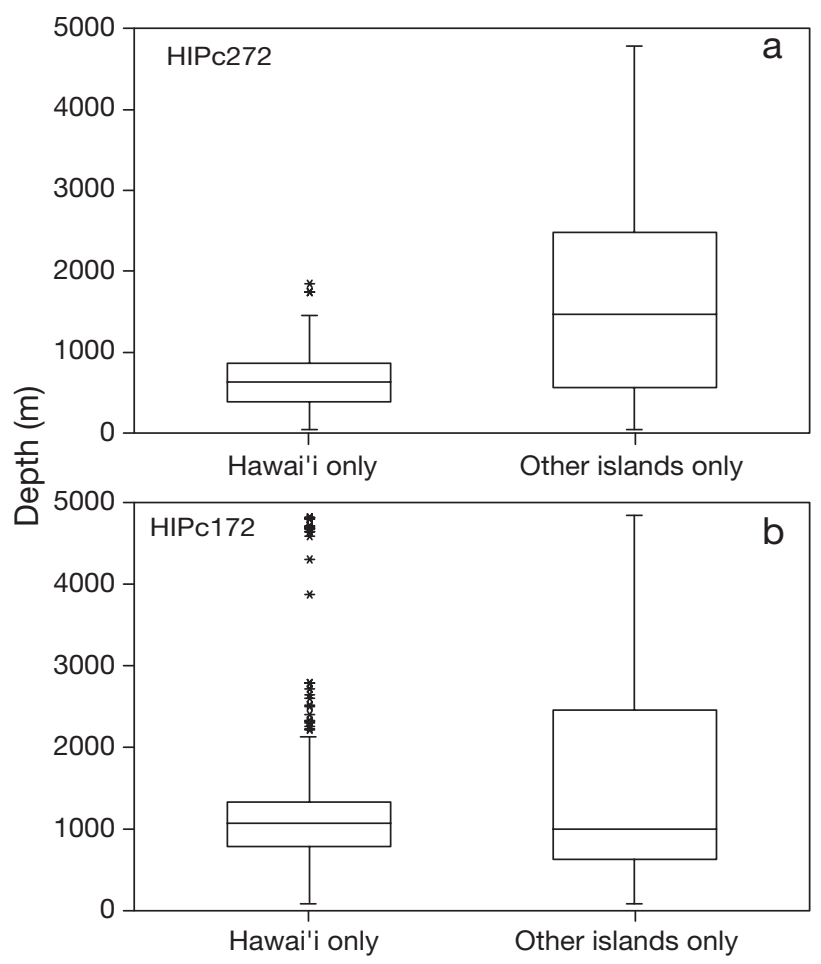

Fig. 5. Pseudorca crassidens. Box plots (line: median; box: interquartile range [IQR]; whiskers: range of datapoints $<1.5 \times$ IQR above/below IQR; asterisks: outliers $>1.5 \times$ IQR above IQR) of depths from satellite-derived locations for 2 individuals when remaining around the island where they were tagged (Hawai'i only) and after they had left the island (other islands only), illustrating wider range in depths used around other islands. (a) HIPc272 tagged in July 2008, (b) HIPc172 tagged in December 2008 maximum distance moved away from the tagging site was only $202 \mathrm{~km}$ (greatest distance $=420 \mathrm{~km}$ ). One tagged individual did move to the east coast of the island of Kaua'i. In the photo-identification study of Baird et al. (2008a) only a small number of identifications were available from Kaua'i and no matches to the rest of the catalog were found. Thus, this is the first evidence that individuals that use waters from O'ahu to Hawai'i also visit Kaua'i.

Based on a comparison of sightings in relation to effort stratified by depth, Baird et al. (2008a) noted that false killer whales around the main Hawaiian Islands appeared to show preference for deeper $(>3000 \mathrm{~m}$ ) portions of their study area. While the sample size was small (18 sightings) and it included 2 sightings of groups that were probably part of the offshore population, a re-analysis restricted to groups from the insular population and with a slightly larger sample size (22 sightings through December 2008) shows the same general trend (R. W. Baird et al. unpubl. data). Results from satellite tagging generally indicated a shallower depth distribution than was evident from the sighting and effort analysis (Table 4). Our sample size of satellite-derived locations for individuals from the insular population is much larger (over 3000 locations) and generally avoids the geographic biases present in the survey data, where survey efforts were restricted to leeward sides of the islands and focused in relatively shallow waters. All but one of our tagged insular false killer whales used waters $>1000 \mathrm{~m}$ depth, but only 5 (4 of the 5 that left the island of Hawai'i and 1 individual that did not) used waters $>3000 \mathrm{~m}$ depth (Table 4). Our sample of locations from satellite-tagged individuals includes correlated series of depths for each individual that are influenced by their short-term movement patterns (e.g. Fig. 3), which may explain part of the difference from the sighting and survey effort analysis. However, movements of false killer

Table 5. Pseudorca crassidens.Comparisons of habitat use of insular false killer whales on windward and leeward sides of the Hawaiian Islands

\begin{tabular}{|c|c|c|c|c|c|c|c|c|}
\hline \multirow{3}{*}{$\begin{array}{l}\text { Catalog } \\
\text { ID }\end{array}$} & \multicolumn{2}{|c|}{ No. of locations } & \multicolumn{4}{|c|}{ - Median (max.) distance $(\mathrm{km})$} & \multicolumn{2}{|c|}{ Median (max.) depth (m) } \\
\hline & \multirow[t]{2}{*}{ Windward } & \multirow[t]{2}{*}{ Leeward } & \multicolumn{2}{|c|}{ To $200 \mathrm{~m}$ isobath } & \multicolumn{2}{|c|}{ From shore } & \multirow[t]{2}{*}{ Windward } & \multirow[t]{2}{*}{ Leeward } \\
\hline & & & Windward & Leeward & Windward & Leeward & & \\
\hline HIPc107 & 83 & 48 & $5.1(15.3)$ & $4.0(90.8)$ & $9.9(21.0)$ & $19.3(95.9)$ & $602(2138)$ & $581(4833)$ \\
\hline HIPc272 & 206 & 48 & $8.0(19.3)$ & $12.6(77.3)$ & $12.4(22.9)$ & $23.1(83.1)$ & $623(1003)$ & 1069 (4767) \\
\hline HIPc179 & 37 & 29 & 7.5 (19.9) & $11.1(30.1)$ & $14.9(33.7)$ & $4.3(21.3)$ & 805 (1673) & 297 (1088) \\
\hline HIPc202 & 352 & 345 & $9.3(25.2)$ & $10.0(33.4)$ & $13.2(27.6)$ & $14.7(37.9)$ & $679(1958)$ & $824(4652)$ \\
\hline HIPc145 & 111 & 91 & $2.9(15.3)$ & $3.5(22.3)$ & $5.5(17.4)$ & $7.0(27.4)$ & 338 (966) & 424 (2105) \\
\hline HIPc205 & 208 & 225 & $6.1(20.9)$ & $5.5(27.3)$ & $9.4(23.4)$ & $10.8(31.7)$ & $578(1874)$ & 633 (2619) \\
\hline HIPc209 & 327 & 177 & $4.5(18.0)$ & $2.8(32.8)$ & $7.5(20.2)$ & $7.7(39.3)$ & 429 (1517) & $412(3401)$ \\
\hline $\mathrm{HIPc}_{\mathrm{C}} 213$ & 144 & 158 & $7.6(26.1)$ & $5.2(25.1)$ & $11.0(28.4)$ & $9.5(28.7)$ & $632(1447)$ & 535 (1940) \\
\hline HIPc172 & 259 & 146 & $11.3(36.6)$ & $21.2(57.5)$ & $16.1(43.7)$ & $29.4(87.3)$ & $790(3525)$ & 1295 (4847) \\
\hline Mean & 141.7 & 191.0 & $6.9(21.8)$ & $8.4(44.0)$ & $11.1(26.5)$ & $14.0(50.3)$ & 608 (1789) & 674 (3361) \\
\hline $\mathrm{SD}$ & 100.6 & 109.6 & $2.7(6.7)$ & $6.3(25.0)$ & $3.3(8.1)$ & $8.1(29.5)$ & $142(764)$ & $318(1472)$ \\
\hline
\end{tabular}



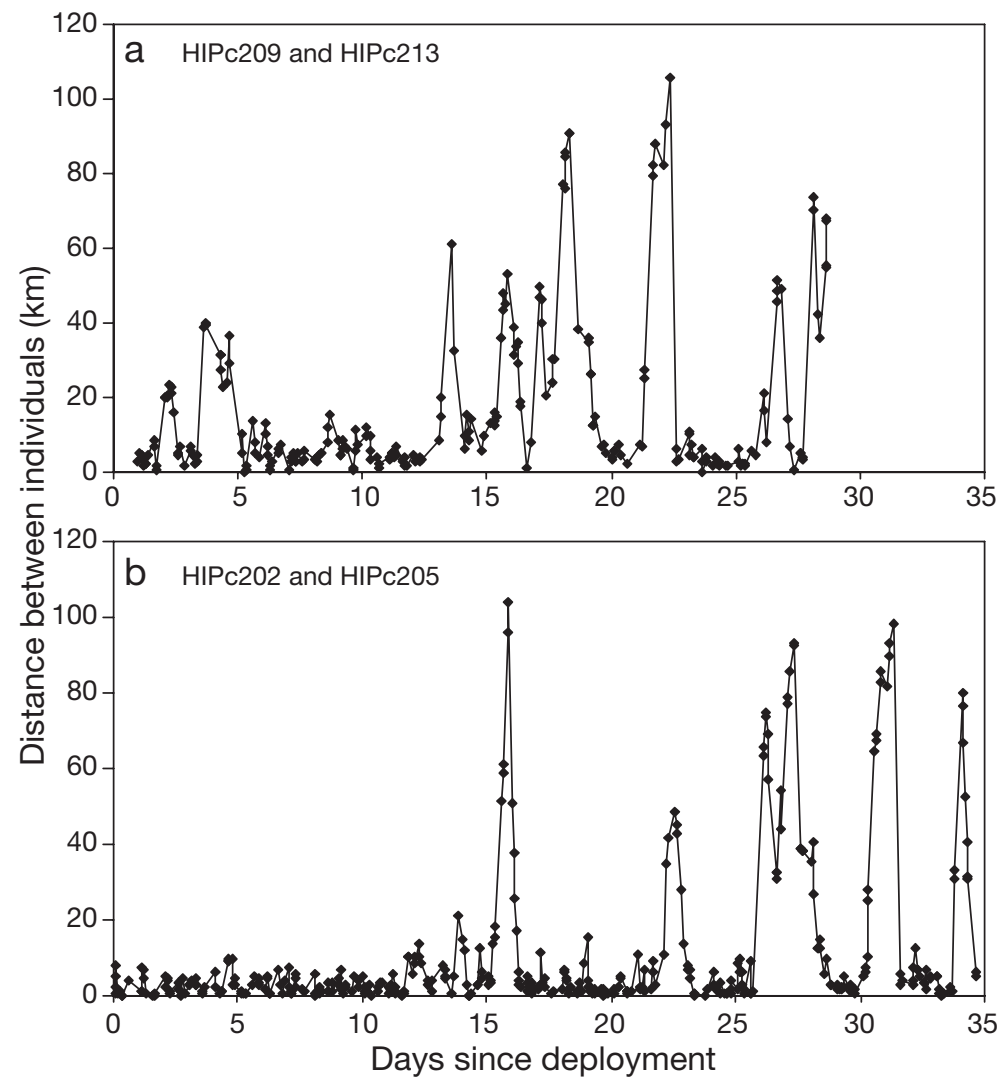

Fig. 6. Pseudorca crassidens. Distance between pairs of individuals tagged on the same day over the (a) first 29 and (b) $35 \mathrm{~d}$ after deployment. Distances between pairs calculated only using filtered satellitederived locations obtained within 5 min of each other. These graphs illustrate that while individuals within a group may remain associated (within $10 \mathrm{~km}$ ) for extended periods (up to $11 \mathrm{~d}$ for HIPc202 and HIPc205), they may disassociate and re-associate, with distances between individuals of over $100 \mathrm{~km}$

whales probably reflect movements of their primary prey, large game fishes such as yellowfin tuna Thunnus albacares, albacore tuna T. alalunga, skipjack tuna Katsuwonus pelamis, mahimahi Coryphaena hippurus and ono Acanthocybium solanderi, among others (Baird et al. 2008a). Although little is known of the movements of these fish species in Hawaiian waters, they are all wide-ranging and their distribution probably varies in association with large-scale eddy systems (Seki et al. 2002) as well as seasonally and inter-annually (Polovina et al. 2009); thus, some of the differences in habitat use between our satellite data analyses (2007 to 2009) and the sightings and effort analyses (2000 to 2006) could simply reflect differences in prey densities around the islands between the periods that the respective data were obtained.

There are a number of differences in environmental conditions between the windward and leeward sides of the main Hawaiian Islands. Shallow water $(<200 \mathrm{~m})$ tends to extend farther offshore on the leeward sides of the islands, primarily due to Penguin Bank, which extends west southwest from the west side of Moloka'i (Fig. 1). With the strong winds funneling through the channels between the islands, there is increased eddy formation on the leeward side of the islands that should increase local productivity (e.g. Seki et al. 2001, 2002). Rainfall is greater on the windward sides of the islands (Giambelluca et al. 1986), but the sea surface currents generally flow in a westerly direction (Flament et al. 1996); thus, any fresh water and nutrient inputs from the islands are likely to have only a nearshore influence on the windward sides and a diluted but more widespread influence on the leeward sides. Previously the only available information to assess use of the windward sides of the islands were sightings from aerial surveys undertaken by Mobley et al. (2000), which did detect false killer whales off both the leeward and windward sides of the islands. There is evidence that individuals from one island-associated population, Blainville's beaked whales Mesoplodon densirostris, do appear to restrict their movements largely to the leeward side of the island of Hawai'i (Schorr et al. 2009a). All of the insular false killer whales were satellite tagged on the leeward side of the islands, yet with the exception of the 1 individual for which only $2 \mathrm{~d}$ of locations were obtained, all individuals spent time both on the leeward and windward sides of the islands. Taking into account only the 9 individuals with 60 or more locations, on average the tagged individuals had approximately $42 \%$ of their locations on the windward side of the islands, and 3 of the 9 individuals had more locations on the windward sides than on the leeward sides (Table 5). Median depths were simi-

Table 6. Pseudorca crassidens. Minimum rates of horizontal movements of tagged insular false killer whales using pairs of locations obtained between 2 and $6 \mathrm{~h}$ apart

\begin{tabular}{|lcc|}
\hline $\begin{array}{l}\text { Catalog } \\
\text { ID }\end{array}$ & $\begin{array}{c}\text { Median (range) rate of } \\
\text { horizontal movements }\left(\mathrm{km} \mathrm{h}^{-1}\right)\end{array}$ & $\mathrm{n}$ \\
\hline HIPc272 & $5.71(1.67-14.41)$ & 50 \\
HIPc179 & $5.53(2.32-10.44)$ & 9 \\
HIPc202 & $4.38(0.36-16.38)$ & 112 \\
HIPc145 & $4.64(0.67-11.94)$ & 24 \\
HIPc205 & $5.41(0.49-16.49)$ & 63 \\
HIPc209 & $4.99(0.51-18.61)$ & 76 \\
HIPc213 & $4.53(1.21-17.63)$ & 40 \\
HIPc172 & $4.24(0.43-13.30)$ & 131 \\
Grand mean & $4.93(4.24-5.71)$ & 8 \\
\hline
\end{tabular}


lar on the windward and leeward sides, as was the median distance from shore and distance to the $200 \mathrm{~m}$ isobath (Table 5). However, there were significant differences in the maximum depth, distance from shore and distance from the $200 \mathrm{~m}$ isobath on the windward and leeward sides of the islands, with individuals extending farther offshore and into greater maximum depths on the leeward sides of the islands (Table 5).

We found considerable variation in movement patterns and habitat use among individuals within a group (e.g. Fig. 6, Table 4), between individuals in different groups (e.g. Fig. 3) and within individuals depending on whether they were around the island of Hawai'i or around other islands (Fig. 5). Individuals tagged off the island of Hawai'i in July 2008 remained associated with the island for an extended period (Table 4, Fig. 3), moving from the site of tagging off the west side of the island to the east side and back again on multiple occasions, for 47 to $58 \mathrm{~d}$. It is somewhat surprising that a large group of false killer whales could repeatedly re-visit an area over periods of weeks, and yet our encounter rates with this species are extremely low (Baird et al. 2008a). However, these individuals did spend a large proportion of their time on the windward side of the island and in areas off the northwest coast of the island where survey efforts are limited due to strong winds and swells. It is also clear that movement patterns of insular individuals were extremely variable (e.g. see Figs. $3 \& 4$ ). Based on photo-identification matches among islands, Baird et al. (2008a) had noted that false killer whales regularly moved among the central and eastern-most main Hawaiian Islands, from O'ahu to Hawai'i, although due to long intervals among encounters off different islands there was no information on rates of movements. The 5 tagged individuals that left the island of Hawai'i did so after variable periods in association with the island, from 3 to $59 \mathrm{~d}$ (Fig. 3). One individual tagged in August 2007 only remained associated with the island for approximately $2 \mathrm{~d}$ before making extensive movements among the main Hawaiian Islands, spending time both on the leeward and windward sides of the islands, both nearshore and in deep waters (Table 4), and eventually moving to Kaua'i (a straight line distance of $420.1 \mathrm{~km}$ from the site of tagging) before beginning to return east. The extensive and rapid movements throughout the main Hawaiian Islands and from the leeward to windward sides of the islands suggests that efforts to photo-identify individuals for mark-recapture estimates of population size probably are not greatly biased by geographic biases in sampling effort, particularly since sampling effort off different islands has typically occurred with months or even years between sampling events (Baird et al. 2005, 2008a).
Our results also provide insight into the group dynamics of false killer whales in Hawaiian waters. Based on analyses of association patterns of photoidentified individuals, Baird et al. (2008a) noted that false killer whales have somewhat stable bonds among individuals, lasting over periods of years, but that large groups encountered in the field were probably temporary associations of multiple smaller more stable groups. They also considered individuals and subgroups spread as far as $28 \mathrm{~km}$ apart to be part of single 'groups', as they appeared to move in a coordinated manner in a consistent direction. With location data obtained from multiple individuals at approximately the same time $( \pm 5 \mathrm{~min})$, we were able to assess how individuals move in relation to one another over periods of up to $35 \mathrm{~d}$. Plots of distances among individuals tagged on the same day during July 2008 indicate that individuals were often separated by distances much greater than $20 \mathrm{~km}$ (as much as $105 \mathrm{~km}$, Fig. 6), and would associate (within a few kilometers) and disassociate (spread as far as $105 \mathrm{~km}$ ) over periods of days, lending support to the photo-identification results of Baird et al. (2008a). These results support comments by Reeves et al. (2002) that although false killer whales typically occur in relatively small groups of 10 to 20, the groups usually belong to larger aggregations with hundreds of individuals. Group sizes of false killer whales driven ashore in drive fisheries or documented in mass strandings are often much larger than the groups typically observed in the wild (Ross 1984, Kasuya 1986), also supporting the suggestion that small subgroups are often clustered into larger aggregations. Such a finding is particularly interesting in light of the findings of Reeves et al. (2009), who observed large groups of false killer whales spread over a wide area off the northwestern side of the island of Hawai'i on multiple days in July 1989. This is an area that tagged whales in our study repeatedly visited over an extended period (47 to $58 \mathrm{~d}$ ). These results on movements of satellite-tagged individuals lend support to the argument of Reeves et al. (2009) that the large groups they observed in July 1989 were part of the insular population, thus providing support to the suggestion that the insular population has undergone a large decline over the last $20 \mathrm{yr}$.

As noted, NMFS currently considers the longline exclusion zone boundary to be the stock boundary between the Hawai'i insular and Hawai'i 'pelagic' stocks (Carretta et al. 2009). One of the most important findings of this study is that the one offshore individual tagged (123.8 $\mathrm{km}$ from shore) moved inside of the longline fishery exclusion boundary, to within $62 \mathrm{~km}$ of shore (Fig. 4). Baird et al. (2008a) had previously suggested that offshore individuals may approach relatively close to the main Hawaiian Islands based on 
photo-identification of a group spread from 42 to $70 \mathrm{~km}$ offshore that had no matches to their catalog, although no genetic samples were obtained from that group to confirm their population identity. Although individuals from the insular population did not move outside of the longline fishery exclusion boundary, individuals from all 3 groups traveled far offshore (83.1, 87.3 and $95.9 \mathrm{~km}$ from shore, respectively), and during the period when the longline exclusion boundary contracts towards the islands (October through January) the one satellite-tagged individual was documented $16.2 \mathrm{~km}$ from the boundary. This implies that individuals from the insular population potentially move into areas where longline fishing occurs and thus could interact with the fishery, as suggested by high rates of dorsal fin disfigurements in comparison with other populations of small odontocetes (Baird \& Gorgone 2005, T. Cullins unpubl. data). Such movements also indicate that individuals from the insular population probably overlapped broadly with longline fishing effort before the establishment of the exclusion zones in 1992 (see He et al. 1997). The rates of movement documented (mean, $5 \mathrm{~km} \mathrm{~h}^{-1}$; maximum, $18.61 \mathrm{~km} \mathrm{~h}^{-1}$; Table 6) also suggest that movements of insular whales offshore into areas where longline fishing may occur could be rapid, as short as $10 \mathrm{~h}$ for an individual starting close to shore (at least during October through January). Thus, detecting occasional movements into offshore waters where longline fishing may occur could be difficult. Even during the period when 1 whale was documented $16.2 \mathrm{~km}$ from the longline exclusion boundary, the time interval since the last location $(3.4 \mathrm{~h})$ and before the next location $(7.4 \mathrm{~h})$ were long enough that the tagged whale could have moved into areas where longline fishing was occurring. Although the longline exclusion zone boundary is fixed, with 2 seasonal variations (February through September, October through January), fishing effort in terms of the proximity to the boundary may vary considerably within one of the seasonal periods. Based on 2008 data from the Federal Longline Logbook Program, fishing effort in October 2008 was concentrated closer to the boundary around the main Hawaiian Islands than in November or December 2008 (D. Hamm pers. comm.).

Whether movements of individuals from either the offshore or insular populations of false killer whales in Hawai'i vary seasonally is unknown. Although we have movement data from the insular population for 5 mo of the year, for 2 of those months (December, January) we have information from only a single individual. In addition, although we have tracks from 9 different individuals from the insular population lasting longer than $10 \mathrm{~d}$, tags were deployed on only 4 different days. While individuals tagged within the same group did not always travel together (Fig. 6), their fre- quent re-associations suggest that the overlapping tag data from different individuals are not completely independent (e.g. Video S1). As well, the variability in short-term movement patterns apparent even with our limited sample (Fig. 3) indicates that tagging more individuals would be extremely informative in understanding movement patterns of this population. Tagging additional individuals from the offshore population is clearly needed, both to further assess movements in relation to the longline fishery boundary and the insular population, as well as to determine whether individuals from the offshore population move across the US Exclusive Economic Zone boundary, where they may also interact with international longline fishing. However, encounter rates with false killer whales in offshore waters are extremely low (Barlow 2006, Barlow \& Rankin 2007) and the logistics for tagging whales offshore are considerably more difficult than for nearshore. Assessing movements of the insular population during the period when longline fishing may occur as close as $45 \mathrm{~km}$ from the main Hawaiian Islands (October through January) would be particularly important in determining whether and how often individuals from that population may interact with the longline fishery.

Given the current small size of the insular population (Baird et al. 2005), the declining trend in sighting rates from aerial surveys (J. Mobley unpubl. data), and the evidence of a probable large decline in population size (Reeves et al. 2009), it is clear that any mortality or serious injury due to longline fishery interactions could have a detrimental effect on the population. The PBR level for the insular stock is 0.8 individuals $\mathrm{yr}^{-1}$ (Carretta et al. 2009); thus, even a low level of mortality may have a detrimental effect on the population. Therefore, efforts should be made to assess longline fishery interactions in the areas where the longline boundary approaches closest to the main Hawaiian Islands. In addition, using a simple distance-fromshore boundary between the insular and offshore populations is not biologically realistic; our results indicate that these 2 populations may broadly overlap in their ranges rather than being separated by a distinct geographical boundary. This situation is similar to populations of killer whales Orcinus orca along the west coast of North America, with 2 discrete populations feeding on similar prey (i.e. 'northern residents' and 'southern residents') that broadly overlap in range along the coast of Washington and British Columbia (Ford 2006).

Acknowledgements. Field work, during which tagging was undertaken, was funded by the US Navy (through the Southwest Fisheries Science Center and Woods Hole Oceanographic Institution), the Wild Whale Research Foundation, and the Pacific Islands Fisheries Science Center. Funding for 
tags and tag development was provided by the Northwest Fisheries Science Center and Dolphin Quest. We thank J. Barlow, D. Johnston, B. Southall and P. Tyack for coordinating funding. We thank J. Aschettino, J. Barlow, A. Bendlin, A. Douglas, G. Legay, E. Oleson, D. Roberts and M. Sakai for assistance in the field, A. Gorgone for matching photographs obtained to our photo-identification catalog, M. Deakos, E. Oleson, D. Perrine, D. Salden and T. Cullins for contributing photographs to assess sighting history, D. Holzer for providing GIS analyses of location data, and K. Forney, E. Oleson and 2 anonymous reviewers for helpful reviews of the manuscript. This research was undertaken under Scientific Research Permit No. 731-1774 from the NMFS Office of Protected Resources.

\section{LITERATURE CITED}

Andrews RD, Pitman RL, Balance LT (2008) Satellite tracking reveals distinct movement patterns for Type B and Type C killer whales in the southern Ross Sea, Antarctica. Polar Biol 31:1461-1468

Baird RW, Gorgone AM (2005) False killer whale dorsal fin disfigurements as a possible indicator of long-line fishery interactions in Hawaiian waters. Pac Sci 59:593-601

Baird RW, Gorgone AM, Webster DL, McSweeney DJ and others (2005) False killer whales around the main Hawaiian Islands: an assessment of inter-island movements and population size using individual photo-identification. Report prepared under Order No. JJ133F04SE0120 from the Pacific Islands Fisheries Science Center, National Marine Fisheries Service, Honolulu, HI. Available at: www.cascadiaresearch.org/robin/hawaii.htm

Baird RW, Gorgone AM, McSweeney DJ, Webster DL and others (2008a) False killer whales (Pseudorca crassidens) around the main Hawaiian Islands: long-term site fidelity, inter-island movements, and association patterns. Mar Mamm Sci 24:591-612

Baird RW, Webster DL, Mahaffy SD, McSweeney DJ, Schorr GS, Ligon AD (2008b) Site fidelity and association patterns in a deep-water dolphin: rough-toothed dolphins (Steno bredanensis) in the Hawaiian Archipelago. Mar Mamm Sci 24:535-553

Baird RW, Schorr GS, Webster DL, McSweeney DJ, Gorgone AM, Chivers SJ (2008c) A survey to assess overlap of insular and offshore false killer whales (Pseudorca crassidens) off the island of Hawai'i. Report prepared under Order No. AB133F07SE4484 for the Pacific Islands Fisheries Science Center, National Marine Fisheries Service, Honolulu, HI. Available at: www.cascadiaresearch.org/robin/ hawaii.htm

Baird RW, Gorgone AM, McSweeney DJ, Ligon AD and others (2009) Population structure of island-associated dolphins: evidence from photo-identification of common bottlenose dolphins (Tursiops truncatus) in the main Hawaiian Islands. Mar Mamm Sci 25:251-274

Barlow J (2006) Cetacean abundance in Hawaiian waters estimated from a summer/fall survey in 2002. Mar Mamm Sci 22:446-464

Barlow J, Rankin S (2007) False killer whale abundance and density: preliminary estimates for the PICEAS study area south of Hawaii and new estimates for the US EEZ around Hawaii. Admin Rep Southwest Fisheries Science Center, LJ-07-02, La Jolla, CA

Behrenfeld MJ, O'Malley RT, Siegel DA, McClain CR and others (2006) Climate-driven trends in contemporary ocean productivity. Nature 444:752-755
Beyer HL (2004) Hawth's analysis tools for ArcGIS ${ }^{\circledR}$. Version 3.21. www.spatialecology.com/htools (accessed: 12 September 2005)

Carretta JV, Forney KA, Lowry MS, Barlow J, Baker J, Hanson B, Muto MM (2007) U.S. Pacific marine mammal stock assessments: 2007. NOAA Tech Memo NOAA-TMNMFS-SWFSC-414

Carretta JV, Forney KA, Lowry MS, Barlow J and others (2009) U.S. Pacific marine mammal stock assessments: 2008. NOAA Tech Memo NMFS-SWFSC-434

Chivers SJ, Baird RW, McSweeney DJ, Webster DL, Hedrick NM, Salinas JC (2007) Genetic variation and evidence for population structure in eastern North Pacific false killer whales (Pseudorca crassidens). Can J Zool 85:783-794

Flament P, Kennan S, Lumpkin R, Sawyer M, Stroup ED (1996) Ocean atlas of Hawai'i. www.soest.hawaii.edu/ hioos/oceanatlas/index.htm (accessed 17 August 2009)

Ford JKB (2006) An assessment of critical habitats of resident killer whales in waters off the Pacific coast of Canada. Can Sci Advis Secretariat Res Doc 2006/072. Available at: www.dfo-mpo.gc.ca/csas/Csas/Publications/ResDocsDocRech/2006/2006_072_e.htm

Forney KA, Kobayashi D (2007) Updated estimates of mortality and injury of cetaceans in the Hawaii-based longline fishery, 1994-2005. NOAA Tech Memo NMFS-SWFSC412

Forney KA, Barlow J, Muto MM, Lowry M and others (2000) U.S. Pacific marine mammal stock assessments: 2000. NOAA Tech Memo NOAA-TM-NMFS-SWFSC-300

Giambelluca TW, Nuller MA, Schroeder TA (1986) Rainfall atlas of Hawai'i. State of Hawai'i Department of Land and Natural Resources Report R76, Honolulu, HI

Gilman E, Clarke S, Brothers N, Alfaro-Shigueto J and others (2007) Shark depredation and unwanted bycatch in pelagic longline fisheries: industry practices and attitudes, and shark avoidance strategies. Western Pacific Regional Fishery Management Council, Honolulu, HI

He X, Bigelow KA, Boggs CH (1997) Cluster analysis of longline sets and fishing strategies within the Hawaii-based fishery. Fish Res 31:147-158

Kasuya T (1986) False killer whales. In: Tamura T, Ohsumi S, Arai S (eds) Report of investigation in search of solution for dolphin-fishery conflict in the Iki Island area. Japan Fisheries Agency, Tokyo, p 178-187

McSweeney DJ, Baird RW, Mahaffy SD (2007) Site fidelity, associations and movements of Cuvier's (Ziphius cavirostris) and Blainville's (Mesoplodon densirostris) beaked whales off the island of Hawai'i. Mar Mamm Sci 23: 666-687

Mobley JR, Spitz SS, Forney KA, Grotefendt R, Forestell PH (2000) Distribution and abundance of odontocete species in Hawaiian waters: preliminary results of 1993-98 aerial surveys. Admin Rep LJ-00-14C, Southwest Fisheries Science Center, La Jolla, CA

Norris KS, Würsig B, Wells RS, Würsig M, Brownlee SM, Johnson CM, Solow J (1994) The Hawaiian spinner dolphin. University of California Press, Berkeley, CA

Polovina JJ, Abecassis M, Howell EA, Woodworth P (2009) Increases in the relative abundance of mid-trophic level fishes concurrent with declines in apex predators in the subtropical North Pacific, 1996-2006. Fish Bull 107: 523-531

Purves PE, Pilleri G (1978) The functional anatomy and general biology of Pseudorca crassidens (Owen) with a review of the hydrodynamic and acoustics in Cetacea. Investig Cetacea 9:67-227 
Reeves RR, Stewart BS, Clapham PJ, Powell JA (2002) National Audubon Society guide to marine mammals of the world. Alfred A. Knopf, New York

Reeves RR, Leatherwood S, Baird RW (2009) Evidence of a possible decline since 1989 in false killer whales (Pseudorca crassidens) around the main Hawaiian Islands. Pac Sci 63:253-261

Ross GJB (1984) The smaller cetaceans of the south east coast of southern Africa. Ann Cape Prov Mus (Nat Hist) 15: $173-410$

Schorr GS, Baird RW, Hanson MB, Webster DL, McSweeney DJ, Andrews RD (2009a) Movements of the satellitetagged Blainville's beaked whales off the island of Hawai'i. Endang Species Res 10:203-213

Editorial responsibility: Sascha Hooker, St. Andrews, UK
Schorr GS, Baird RW, Webster DL, McSweeney DJ, Hanson MB, Polovina J, Andrews RD (2009b) Satellite tagging of melon-headed whales in Hawai'i reveals widely dispersed movement patterns. 18th Biennial Conference on the Biology of Marine Mammals, Quebec City, Canada, 12-16 October 2009 (Abstract)

Seki MP, Polovina JJ, Brainard RE, Bidigare RR, Leonard CL, Foley DG (2001) Biological enhancement at cyclonic eddies tracked with GOES thermal imagery in Hawaiian waters. Geophys Res Lett 28:1583-1586

Seki MP, Lumpkin R, Flament P (2002) Hawaii cyclonic eddies and blue marlin catches: the case study of the 1995 Hawaiian International Billfish Tournament. J Oceanogr 58: 739-745

Submitted: August 18, 2009; Accepted: November 23, 2009 Proofs received from author(s): January 28, 2010 